\title{
Transient Adenocorticotropic Hormone deficiency in an infant
}

\author{
Nasir A.M. Al Jurayyan*1, Sharifah D.A. Al Issa ${ }^{1}$, Rushaid N.A. Al Jurayyan ${ }^{2}$ \\ ${ }^{1}$ Departments of Pediatrics, College of Medicine and King Khalid University Hospital, King Saud University, Riyadh, Saudi Arabia \\ ${ }^{2}$ Radiology and Medical Imaging, College of Medicine and King Khalid University Hospital, King Saud University, Riyadh, Saudi \\ Arabia
}

Received: September 4, 2016

DOI: $10.5430 /$ crcp.v4n1p56
Accepted: December 6, $2016 \quad$ Online Published: December 13, 2016

URL: http://dx.doi.org/10.5430/crcp.v4n1p56

\begin{abstract}
Background: Isolated Adenocorticotropin Hormone (ACTH) deficiency is a rare disorder, characterized by secondary adrenal insufficiency with a low or absent cortisol production, normal secretion of other pituitary hormones and absence of structural pituitary defects.

Case summary: The patient was the product of a 28 weeks gestation, clomiphen induced to a 40-year-old, gestational diabetic mother. He was ventilated for 30 days, and was diagnosed to have grade IV Retina of Prematurity (ROP). He suffered from recurrent attacks of hypoglycemic, blood sugar of $1.6 \mathrm{mmol} / \mathrm{L}$, low serum cortisol $65 \mathrm{nmol} / \mathrm{L}$ (normal; 150-630), and ACTH of $1.5 \mathrm{pmol} / \mathrm{L}$ (normal; 1.6-13.9), with suppressed serum insulin and normal thyroid, growth hormone and gonadal functions. Magnetic Resonance Imaging (MRI) was unremarkable. He was started on hydrocortisone $2.5 \mathrm{mg}$ twice daily for two years, which was then slowly tapered and stopped. Later Serum cortisol was $175 \mathrm{nmol} / \mathrm{L}$, and ACTH of $5.5 \mathrm{pmol} / \mathrm{L}$ with a normal shot ACTH stimulation test.

Conclusions: This case of a premature baby who presented with recurrent hypoglycemia had an isolated ACTH deficiency that proved to be transient. The pediatricians need to be aware of the existence of such condition.
\end{abstract}

Key Words: Adenocorticotropin Hormone, Isolated, Hypoglycemic, Transient

\section{INTRODUCTION}

Isolated Adenocorticotropin Hormone (ACTH) deficiency is a rare disorder that characterized by secondary adrenal insufficiency with low or absent cortisol production, normal secretion of other pituitary hormone and absence of structural pituitary defects. ${ }^{[1]}$ The defect is usually at the pituitary level but can be at the hypothalamus. ${ }^{[2]}$ Most cases are secondary to autoimmune process such lymphocytic hypophysitis. ${ }^{[3,4]}$ It may also occur after traumatic head injury ${ }^{[5]}$ and pituitary irradiation. ${ }^{[6]}$ Genetic cases are encountered in neonatal and childhood isolated ACTH deficiency. ${ }^{[7]}$ It might be associ- ated with transient growth hormone (GH deficiency $)^{[8]}$ or thyroid disorders. ${ }^{[9]}$

In this report, we describe a premature baby who presented with recurrent hypoglycemia and proved to have transient isolated ACTH deficiency. The practicing pediatrician should be aware of the existence of such disorder.

\section{CASE REPORT}

The patient was the product of a 28 weeks gestation, clomiphene induced to a 40-year-old mother, who was suffering from gestational diabetes managed with diet. She

\footnotetext{
*Correspondence: Nasir A.M. Al Jurayyan, M.D.; Email: njurayyan@gmail.com; Address: Department of Paediatrics (39), College of Medicine \& King Khalid University Hospital, P.O. Box 2925, Riyadh 11461, King Saud University, Riyadh, Saudi Arabia. 
was para $1+0$. Spontaneous vaginal delivery with a birth weight of one kilogram. He was ventilated for 30 days and diagnosed with grade IV retina of Prematurity (ROP) which required laser therapy. There was no intraventricular hemorrhage. The patient suffered from recurrent attacks of hypoglycemia. At a blood sugar of $1.6 \mathrm{mmol} / \mathrm{L}$, serum concentration of cortisol was low at $65 \mathrm{nmol} / \mathrm{L}$ (normal; 150-630), with also low ACTH level of $1.5 \mathrm{pmol} / \mathrm{L}$ (normal; 1.6-13.9). Serum concentration of growth hormone $(\mathrm{GH})$ was 15,12 and $8.5 \mathrm{ng} / \mathrm{ml}$ (normal; >10) serum concentration of insulin was $6.3 \mathrm{~m} \mu / \mathrm{ml}$ (normal; 5-21). Normal thyroid function tests; TSH of $4 \mathrm{mU} / \mathrm{L}$ (normal; 0.5-5) and FT4 of $15 \mathrm{pmol} / \mathrm{L}$ ( normal; 10-30) Normal hypothalamic pituitary gonadal function; LH of $3.9 \mu / \mathrm{L}$ (normal; 0.5-3) and FSH of 1.3 U/L (normal; 1-5). Unremarkable MS/MS and VLCFA and urine organic acids. Magnetic Resonance Imaging (MRI) was unremarkable, see Figure 1.

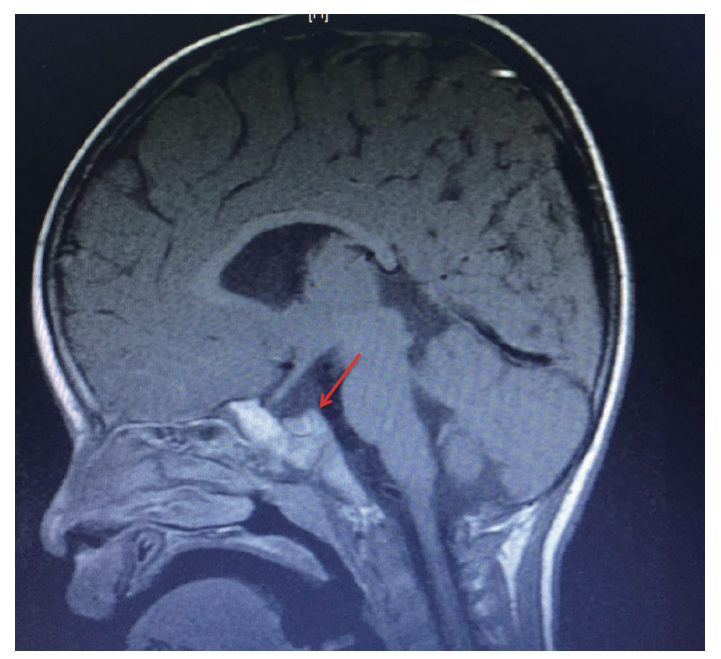

Figure 1. Sagittal view of pituitary Magnetic Resonance Imaging (MRI), showing normal pituitary gland (arrow)

He was started on hydrocortisone $2.5 \mathrm{mg}$ twice daily for two years that was then slowly tapered and stopped. Currently at the age of seven years his adrenal function was normal, serum concentration level was $175 \mathrm{nmol} / \mathrm{L}$ and serum ACTH of $5.5 \mathrm{pmol} / \mathrm{L}$, with a normal response to short ACTH stimulation test (see Table 1). He remains well and growing normally and asymptomatic.

\section{Discussion}

Adrenal insufficiency is caused by either primary adrenal failure, mostly due to autoimmune adrenalism or hypothalamic pituitary adrenal impairment of the corticotropic axis, predominantly due to pituitary or hypothalamic disorders. It is rare, but life threatening when over looked. ${ }^{[10]}$ The diagnosis of isolated ACTH deficiency was based on clinical symptoms of hypoglycemic and low serum concentration of cortisol and ACTH, while the remaining pituitary hormones were normal. The pituitary hypothalamic structure was normal on MRI. ${ }^{[1,2]}$ The patient improved with hydrocortisone therapy.

Table 1. ACTH stimulation test

\begin{tabular}{|l|c|c|}
\hline Adrenal function & ACTH & Cortisol \\
(Base-line Results) & $(1.6-13.9 \mathrm{pmol} / \mathrm{L})$ & $(150-630 \mathrm{nmol} / \mathrm{L})$ \\
& $5.5 \mathrm{pmol} / \mathrm{L}$ & $175 \mathrm{nmol} / \mathrm{L}$ \\
\hline Post Stimulation Cortisol & $30 \mathrm{~min}$ & $60 \mathrm{~min}$ \\
& 480 & 750 \\
\hline
\end{tabular}

The present case report represent a patient with concurrent isolated ACTH deficiency in a premature infant who developed retina of prematurity (ROP) which required laser therapy. This may have been an acute stress related a disease of the elderly polymyalgia rheumatica (PMR), was associated with transient ACTH, as well as in the elderly, critically ill patient. ${ }^{[11,12]}$ Pathogenic significance of adrenal steroid status in relation to inflammatory cytokinesis (Interleukemia). Systemic inflammation in common critical illness. ${ }^{[11,12]}$ The concept of depressed adrenal function associated with the clinical picture of shock and systemic inflammation which can lead to suppression of ACTH synthesis or release and suppression of adrenal cortical synthesis is well known. ${ }^{[12,13]}$

The possible pathophysiologic mechanism leading to this is poorly understood. A combination of factors are likely involved. Direct damage to the hypothalamic-pituitaryadrenal (HPA) axis components, ischemic injury to the metabolically active adenocortical cells. Also the patient's own immune and inflammatory response appears to play a role.

Prostaglandin (PGE) effects on the hypothalamic pituitary adrenal (HPA) axis activation induced by the inflammatory cytokines has long been suggested. ${ }^{[14-16]}$ However, the importance and identity of the PG medicated process have remained to be identified.

\section{Conclusion}

This case of premature baby who presented with recurrent attacks of hypoglycemia and isolated ACTH deficiency which proved to be transient should alert the practicing pediatrician to the co-existence of such disorders and try to find an explanation for the possible mechanism.

\section{ACKNOWLEDGEMENTS}

The authors would like to thank Mrs. Cecile Sael and Miss Hadeel N. Al Jurayyan for her help in preparing this manuscript.

\section{Conflicts OF InTEREST Disclosure}

The authors declare no conflicts of interest. 


\section{REFERENCES}

[1] Andriloli M, Pecori Giraldi F, Cavagnini F. Isolated Corticotrophin deficiency pituitary. 2006; 9(4): 289-95.

[2] Al Jurrayan NAM. Isolated Adrenocorticotropin deficiency as a rare cause of hypoglycaemia in children. Horm Res. 1995; 44: 238-40. https://doi.org/10.1159/000184633

[3] Escobar-Morreale H, Serrano-Gotarreadona J, Varela C. Isolated Adrenocorticotropic hormone deficiency due to probable lymphocytic hypophysitis in a man. Journal of Endocrinological Investigation. 1994; 17: 127-31. PMid: 8006333. https://doi.org/10.1 $007 / \mathrm{BF} 03347700$

[4] Kasperlik-Zaluska AA, Czarnocka B, Czech W, et al. Secondary adrenal insufficiency associated with autoimmune disorders, A report of twenty five cases. Clin Endocrinol (Oxf). 1998; 49(6): 779-83. https://doi.org/10.1046/j.1365-2265.1998.00611.x

[5] Scoble JE, Harvard CW. Anosmia and Isolated ACTH deficiency following a road traffic accident: Case report. J Neurosurg. 1990; 73(3): 453-4. PMid: 2166780. https://doi.org/10.3171/jns . $1990.73 \cdot 3 \cdot 0453$

[6] Sakai H, Yoshioka K, Yamagami K, et al. Complete adrenocorticotropin deficiency after radiation therapy for brain tumor with a normal growth hormone reserve. Intern med. 2002; 41: 453-7. PMid: 12135178. https://doi.org/10.2169/internalmedi cine. 41.453

[7] Metherell LA, Savage MO, Dattani M, et al. TPIT mutations are associated with early onset, but not late onset isolated ACTH deficiency. Eur J Endocrinol. 2004; 151: 463-5.

[8] Hochberg Z, Hardoff D, Atias D, et al. Isolated ACTH deficiency with transitory GH deficiency. J Endocrinol Invest. 1985; 8(1): 67-70. PMid: 2985687. https://doi.org/10.1007/BF03350645
[9] Hiraiwa T, Furutama D, Sakane S, et al. Isolated Adrenocorticotropic hormone deficiency with transient thyroiditis inducing an adrenal crisis. Med Princ Pract. 2007; 16: 230-3. PMid: 17409760. https://doi.org/10.1159/000100396

[10] AL Jurrayan NA. Primary Adrenal Insufficiency (PAI):A major teaching hospital experience, Riyadh, Saudi Arabia. Int J Clinical Therapeutic and Diagnosis (IJCTD). 2015; 3(4): 92-4.

[11] Nishi H, Nishi Y, Yagita M, et al. A case of transient ACTH deficiency associated with polymyalgia Rheumatica. Jpn Clin Med. 2010; 1: 25-7. PMid: 23946678.

[12] Kidess AI, Caplan RH, Reynertson RH, et al. Transient Corticotropin deficiency in Critical illness. Mayo Clinic proceedings. https : //doi .org/article/S0025-6196(12)60188-8

[13] Quintos JB, Boney CM. Transient adrenal insufficiency in the premature newborn. Curr Opin Endocrinol Diabetes Obes. 2010; 17(1): 8-12. PMid: 19881342. https://doi.org/10.1097/MED.0b01 3e32833363cc

[14] Alfitori G, Mahmood M, Malik S. Transient secondary hypoadrenalism after a single intra-articular steroid injection-a case report. Endocrine Abstracts. 2009; 19: 89.

[15] Matsuoka Y, Furuyashiki T, Bito H, et al. Impaired adrenocorticotropic hormone response to bacterial endotoxin in mice deficient in prostaglandin E receptor EP1 and EP3 subtypes. Proceeding of the National Academy of Science of the United States of America PNAS. 2003; 100(7): 4132-7. https://doi.org/10.1073/pnas .0633341100

[16] Yoshida M, Murakami M, Ogawa K, et al. Repeated hypoglycemia caused by the overproduction of anti-insulin antibodies and isolated ACTH deficiency in a type 2 diabetic patient receiving insulin therapy. Diabetes Care. 2013; 36(2): 22. https://doi.org/10: $2337 / d c 12-1565$. 